\title{
The Improvement of Quality of Pasta on the Basis of the Vegetable Raw Materials
}

\author{
A.I. Iztaev, G.K. Iskakova, K.S. Kulazhanov, G. Baimagambetova and B.A. Iztaev \\ Almaty Technological University, Kazakhstan, 020000,Almaty. \\ DOI: http://dx.doi.org/10.13005/bbra/1881 \\ (Received: 11 October 2015; accepted: 20 November 2015)

\begin{abstract}
ration of dough promotes improvement of quality of pasta on the basis of flour from grain and bean crops. From the point of view of improvement of quality of pasta by an optimum dosage of corn and chickpea flour in ion ozonated water $20 \%$, concentration of ozone of $2 \mathrm{mg} / \mathrm{l}$ and ions of 1000 pieces/cm3 are being. Use of flour from grain and bean crops expediently for enrichment of pasta valuable food components - proteins, irreplaceable amino acids, vitamins and mineral substances.(Zuber et al,1987;)
\end{abstract}

Key words: Cornmeal, chickpea flour, ion ozonated water, rheological properties, quality of pasta.

. It is necessary to distinguish creation of group of pasta production of the increased nutrition and biological value from the priority directions of development of the range of pasta. The problem of increase of biological value of pasta is solved in a number of the directions, one of which application of nonconventional types of proteinbearing raw materials of a phytogenesis as additional prescription components.(Heldman, 1997).

The pasta belongs to widely consumed products, however they are characterized by low protein content $(100 \mathrm{~g}$ ready pasta satisfy daily need for protein only for 10,4-13,0\%) and unbalanced amino-acid structure, (it is fast a lysine makes $46 \%$, a treonin of $75 \%$ ) (Medvedev,2005;).

In a solution of the problem of deficiency of protein plays use of the following additives of a phytogenesis huge role: leguminous (soy, peas, lentil, haricot, chick-pea); olive (sunflower, flax, colza, sesame); cereals and pseudo-cereals (corn, oats, millet, payza, amaranth); vegetative mass of

\footnotetext{
* To whom all correspondence should be addressed. E-mail: zhanat_2006@mail.ru
}

plants (lucerne, lupine, sugar beet, green tobacco). The important factors defining a choice of raw sources: quantity and composition of protein, biological value, possibility of removal of antinutrients, ability to storage, unpretentiousness to weather changes and productivity of vegetable culture(Osipova G.\&Koryachkina, 2002)

One of perspective types of the additives which are positively influencing color and culinary advantages of pasta is cornmeal. In the food relation the corn is high-valuable raw materials. Grain of corn contains $62-85 \%$ of carbohydrates, $8-20 \%$ of protein, $4-8 \%$ of fat, is rich with mineral salts and vitamins. Therefore use of cornmeal at preparation of pasta allows to increase the biological value of a product (Kosovan\&Polandova,2004;)

Chick-pea is the bean culture rich with protein. Chick-pea surpasses all other types in nutritional value leguminous, including peas, lentil and soy. It is established that grain of chick-pea contains from 20,1 to $32,4 \%$ of protein, $7 \%$ of fat, $48-56 \%$ the of extractive substances without any nitrogen, to $5 \%$ of cellulose and a number of vitamins (Kizatova\&Iztayev,2006). Nutritional value of culture is defined not only amount of protein, but also its quality which depends on balance of 
its amino-acid structure, the content of irreplaceable amino acids, digestibility of proteins and nature of influence on utilization of protein of some adverse factors. On these indicators, and also chick-pea surpasses other bean cultures in amount of the main irreplaceable acids of a lysine, methionine and tryptophan, but has deficiency on sulfur-containing amino acids. The biological value of chick-pea is $68 \%$. This culture surpasses lentil and peas in biological value, conceding to soy.( Pashchenko\&Kurchayeva, 2004;)

Now large-scale researches on application of agents of ion ozonated technology in production of foodstuff, in particular, bakery and pasta are conducted. Bactericidal and oxidation-reduction properties of ion ozonated water promote improvement of safety and hardening of spatial structure of a gluten. (Iskakova et al, 2011;)

Due to the research above, directed on increase of nutrition and biological value of pasta, improvement of their organoleptic and physical and chemical indicators on the basis of use of corn, chickpea flour and ion ozonated water are actual.(Erkebayev, 2006;)

\section{Methods}

For carrying out pilot studies wheat flour of the first grade, cornmeal, chickpea flour, ion ozonated water are used and rheological properties of dough and quality of pasta are defined.

For studying of influence of flour from grain, bean crops and ion ozonated water on rheological properties of dough estimated change of rheological properties of dough on a structure meter, developed on "Technologies of Baking and Pasta Production" chair of Moscow State University of food productions (Structure meter can be applied as the independent device, and as a part of an information and measuring complex.(Kovalskaya,1991;)

The principle of action of a structure meter is based on measurement of force of interaction of the motionless tool and the studied test of a product located on a little table which moves with the set speed. In this device were executed the following mode - definition of elastic and plastic deformations. On a structure meter investigated control option and prototypes of pasta dough weighing 10 g.(Harper,1978;)

Organoleptic and physical and chemical indicators of quality of pasta defined according to the management (.

For determination of appearance (color, a condition of a surface, a form) test of pasta was placed on a smooth surface, carefully mixed and considered.(Akdogan,1999;)

Humidity was defined by drying of carefully crushed pasta in a drying cabinet of the SESh brand $-3 \mathrm{M}$ at a temperature of $1300 \mathrm{C}$ within $40 \mathrm{~min}$. and expressed as a percentage.

Acidity of pasta was determined by method of the water talker and expressed in degrees.

Cooking properties of pasta are characterized by the following indicators: cooking duration to readiness, amount of the absorbed water, losses of solids, durability of the welded products, degree of a stickiness of the welded products.(Henney,2010;)

\section{RESULTS}

Studying of properties of dough for the purpose of regulation of its structural and mechanical and rheological characteristics in the direction of its most rational use by production of products on the basis of flour is important. For development of quality products pasta dough has to have sufficient durability and possess optimum elastoplastic properties. Entering of additives into dough changes its structural and mechanical and rheological indicators that in turn affects and quality of pasta. Rheological properties of semifinished products depend on many factors: way of preparation, temperature, compounding, influence duration etc. Processing of products is followed by difficult physical and chemical and mechanical processes. Flour dough is difficult heterogeneous colloidal disperse system.(Karwe,2008;)

In this regard we investigated influence of corn and chickpea flour in dosages 2,$5 ; 5 ; 7,5$; $10 ; 12.5 ; 15 ; 17,5 ; 20,0 \%$ for rheological properties of dough.

The results of research of elastic and plastic deformations of dough from mix of flour of ion ozonated water, wheat and corn, chickpea without application, on the structure Meter device processed in the Excel program are given in figure 1. Data of the analysis show that with increase in the content of flour from grain and bean crops relative elasticity decreases, and relative plasticity 
increases. In general, according to the analysis of the obtained data, the rheological properties of dough studied on structure meter worsened with increase in dosages of flour from grain and bean crops in dough for pasta: elasticity and tensile properties of dough decreased. However, we also see that introduction to $10 \%$ of cornmeal and to $12,5 \%$ of chickpea flour dough turned out with good rheological properties and didn't concede to quality of dough from wheat flour of the first grade
(control).(Camire,1998;)

The expediency and efficiency of application of different types of food additives, including is estimated on their influence on quality of a product and parameters of process of production: physical and chemical and organoleptic indicators of quality of finished products; nutrition value of finished products; technological mode of production; equipment productivity.(Beaufrand, 1978;)

Table 1. The Influence of cornmeal on quality of pasta

\begin{tabular}{|c|c|c|c|c|c|c|c|c|}
\hline \multirow{3}{*}{$\begin{array}{c}\text { Name of an indicator } \\
\text { Organoleptic indicators: }\end{array}$} & \multirow[t]{3}{*}{ control } & \multicolumn{7}{|c|}{ The ratio of wheat and maize flour, $\%$} \\
\hline & & \multirow[t]{2}{*}{$95: 5$} & \multirow[t]{2}{*}{$92,5: 7,5$} & \multirow[t]{2}{*}{$90: 10$} & \multirow[t]{2}{*}{$87,5: 12,5$} & \multirow[t]{2}{*}{$85: 15$} & \multirow[t]{2}{*}{$\begin{array}{l}82,5: 1 \\
7,5\end{array}$} & \multirow[t]{2}{*}{$80: 20$} \\
\hline & & & & & & & & \\
\hline - condition of a surface & smooth & \multicolumn{3}{|c|}{ smooth } & \multicolumn{2}{|c|}{$\begin{array}{l}\text { smooth with a } \\
\text { slight roughness }\end{array}$} & \multicolumn{2}{|l|}{ rough } \\
\hline - form & $\begin{array}{l}\text { peculiar to } \\
\text { this look }\end{array}$ & \multicolumn{7}{|c|}{ the peculiar } \\
\hline -color & $\begin{array}{l}\text { the light- } \\
\text { cream }\end{array}$ & \multicolumn{3}{|c|}{ light, with a yellowish shade } & \multicolumn{2}{|c|}{$\begin{array}{l}\text { with a yellow } \\
\text { shade }\end{array}$} & \multicolumn{2}{|l|}{ yellow } \\
\hline -taste & $\begin{array}{l}\text { peculiar to } \\
\text { products, } \\
\text { without } \\
\text { foreign } \\
\text { smack }\end{array}$ & \multicolumn{7}{|c|}{ peculiar to products, without foreign smack } \\
\hline -smell & $\begin{array}{l}\text { peculiar to } \\
\text { products, } \\
\text { without } \\
\text { foreign } \\
\text { smell }\end{array}$ & \multicolumn{5}{|c|}{ peculiar, with hardly noticeable smell of cornmeal } & \multicolumn{2}{|c|}{$\begin{array}{l}\text { with a noticeable } \\
\text { smell of cornmeal }\end{array}$} \\
\hline \multicolumn{9}{|l|}{$\begin{array}{l}\text { Physical and chemical } \\
\text { indicators: }\end{array}$} \\
\hline - humidity, \% & 12,7 & 12,8 & 13,0 & 13,0 & 12,8 & 12,5 & 12,8 & 13,0 \\
\hline - acidity, hail & 2,5 & 2,8 & 2,8 & 3,2 & 3,6 & 3,8 & 4,0 & 4,0 \\
\hline $\begin{array}{l}\text { Cooking properties: } \\
\text { - safety of a form }\end{array}$ & $\begin{array}{l}\text { do not } \\
\text { deform, do } \\
\text { not stick } \\
\text { together }\end{array}$ & \multicolumn{5}{|c|}{$\begin{array}{l}\text { do not deform, do not stick } \\
\text { together }\end{array}$} & & \\
\hline $\begin{array}{l}\text { - coefficient of increase } \\
\text { in mass of products }\left(\mathrm{K}_{\mathrm{M}}\right)\end{array}$ & 1,83 & 1,9 & 1,86 & 1,78 & 1,69 & 1,62 & 1,55 & 1,47 \\
\hline $\begin{array}{l}\text { - quantity of SV which } \\
\text { passed into cooking } \\
\text { water, } \%\end{array}$ & 7,0 & 7,0 & 7,0 & 7,28 & 7,98 & 8,6 & 9,2 & 9,87 \\
\hline $\begin{array}{l}\text { - condition of cooking } \\
\text { water }\end{array}$ & $\begin{array}{l}\text { the } \\
\text { transparent }\end{array}$ & the $\operatorname{tr}$ & parent & & not transpa & arent & & \\
\hline readiness, mines & 7 & 7 & 7 & 7 & 8 & 8 & 9 & 10 \\
\hline
\end{tabular}


Due to the above, it was recognized expedient to study influence of flour from grain and bean crops on quality of pasta.

For the purpose of definition of possible dosages of flour in a compounding pasta made of grain and bean crops in vitro on the compounding and technological parameters specified in the management (.Estimated organoleptic, physical and chemical indicators of quality of pasta. Results of researches are given in tables 1 and 2.(Brennan et al, 2008; )

Apparently from the obtained data, the amount of flour from grain and bean crops had impact on structure of dough in the course of a batch, appearance, taste, color and cooking properties of pasta. One of the most significant organoleptic indicators of pasta is, despite its obvious subjectivity, color of products. This indicator has essential impact on the general assessment of quality of pasta and determines the size of demand for this type of products.(Napolina,2008) Considering it, during experiments colors of products was carried out an assessment. At application to $10 \%$ of cornmeal and

Table 2. The influence of chickpea flour on quality of pasta

\begin{tabular}{|c|c|c|c|c|c|c|c|c|}
\hline \multirow[t]{2}{*}{ Name of an indicator } & \multirow[t]{2}{*}{ control } & \multicolumn{7}{|c|}{ The ratio of wheat and maize flour, $\%$} \\
\hline & & $95: 5$ & $92,5: 7,5$ & $90: 10$ & $\begin{array}{c}87,5: 12 \\
5\end{array}$ & $85: 15$ & $82,5: 17$ & $80: 20$ \\
\hline $\begin{array}{l}\text { Organoleptic indicators: } \\
\text { - condition of a surface }\end{array}$ & smooth & \multicolumn{4}{|l|}{ smooth } & \multicolumn{3}{|c|}{ the slightly rough } \\
\hline - form & $\begin{array}{l}\text { peculiar to } \\
\text { this look }\end{array}$ & \multicolumn{7}{|c|}{ the peculiar } \\
\hline -color & $\begin{array}{l}\text { the light- } \\
\text { cream }\end{array}$ & \multicolumn{5}{|c|}{ light, with a yellowish shade } & \multicolumn{2}{|c|}{ light -yellow } \\
\hline -taste & $\begin{array}{l}\text { peculiar to } \\
\text { products, } \\
\text { without } \\
\text { foreign } \\
\text { smack }\end{array}$ & \multicolumn{7}{|c|}{ peculiar to products, without foreign smack } \\
\hline -smell & $\begin{array}{l}\text { peculiar to } \\
\text { products, } \\
\text { without } \\
\text { foreign } \\
\text { smell }\end{array}$ & \multicolumn{5}{|c|}{$\begin{array}{l}\text { peculiar, with hardly noticeable smell of chickpea } \\
\text { flour }\end{array}$} & \multicolumn{2}{|c|}{$\begin{array}{l}\text { with a noticeable } \\
\text { smell of chickpea } \\
\text { flour }\end{array}$} \\
\hline $\begin{array}{l}\text { Physical and chemical } \\
\text { indicators: } \\
\text { - humidity, \% }\end{array}$ & 12,7 & 12,8 & 12,8 & 13,0 & 13,0 & 12,6 & 12,8 & 12,8 \\
\hline - acidity, hail & 2,5 & 2,6 & 2,6 & 2,8 & 3,0 & 3,2 & 3,6 & 3,6 \\
\hline $\begin{array}{l}\text { Cooking properties: } \\
\text { - safety of a form }\end{array}$ & $\begin{array}{l}\text { do not } \\
\text { deform, do } \\
\text { not stick } \\
\text { together }\end{array}$ & \multicolumn{4}{|c|}{ do not deform, do not stick together } & \multicolumn{3}{|c|}{ stick together } \\
\hline $\begin{array}{l}\text { - coefficient of increase } \\
\text { in mass of products }\left(K_{M}\right)\end{array}$ & 1,83 & 1,92 & 1,88 & 1,84 & 1,78 & 1,64 & 1,6 & 1,51 \\
\hline $\begin{array}{l}\text { - quantity of SV which } \\
\text { passed into cooking } \\
\text { water, } \%\end{array}$ & 7,0 & 6,8 & 6,8 & 7,0 & 7,32 & 8,04 & 8,72 & 9,3 \\
\hline $\begin{array}{l}\text { - condition of cooking } \\
\text { water }\end{array}$ & $\begin{array}{l}\text { the } \\
\text { transparent }\end{array}$ & \multicolumn{3}{|c|}{ the transparent } & \multicolumn{4}{|c|}{ not transparent } \\
\hline $\begin{array}{l}\text { - cooking duration to } \\
\text { readiness, mines }\end{array}$ & 7 & 7 & 7 & 7 & 7 & 8 & 8 & 9 \\
\hline
\end{tabular}


to $12,5 \%$ of the chickpea didn't observe essential changes on organoleptic and physical and chemical indicators in comparison with a control sample. Pasta was smooth, the form corresponded to this type of products, color of products doesn't worsen. After cooking of a product was characterized by elasticity, identical with a control sample, cooking water also was transparent, as in a control sample.(Singh,2007;)

However the increase in dosages of flour from grain and bean crops to the mass of wheat flour was worsened by both organoleptic and physical and chemical indicators of pasta. So, with increase in dosages of corn and chickpea flour to $20 \%$ the amount of the solids which passed into cooking water increases to 41,0 and $32,9 \%$, coefficient of increase in mass of products to 19,7 and $17,5 \%$, respectively, in comparison with control.(Brennan, 2012;)

Apparently from these tables 1 and 2 over

Table 3. Influence of ion ozonated Water (concentration of ozone of $2 \mathrm{mg} / \mathrm{l}$ and ions of 1000 pieces/cm3) on cooking properties of pasta

\begin{tabular}{|c|c|c|c|c|c|}
\hline $\begin{array}{l}\text { Ratio of wheat, } \\
\text { grain and bean } \\
\text { flour, } \%\end{array}$ & $\begin{array}{l}\text { Safety of } \\
\text { forms }\end{array}$ & $\begin{array}{l}\text { Coefficient of } \\
\text { increase in mass } \\
\text { of products, } \kappa_{\mathrm{i}}\end{array}$ & $\begin{array}{c}\text { Quantity of } \\
\text { SV which } \\
\text { passed into } \\
\text { cooking water, \% }\end{array}$ & $\begin{array}{l}\text { Cooking } \\
\text { duration to } \\
\text { readiness, } \\
\text { mines }\end{array}$ & $\begin{array}{c}\text { State } \\
\text { cooking water }\end{array}$ \\
\hline & $\begin{array}{l}\text { not deformed, } \\
\text { do not stick together }\end{array}$ & 1,83 & 7,0 & 7 & $\begin{array}{l}\text { the transparent } \\
\text { with cornmeal }\end{array}$ \\
\hline $95: 5$ & $\begin{array}{l}\text { not deformed, } \\
\text { do not stick together }\end{array}$ & 2,1 & 6,37 & 7 & the transparent \\
\hline $92,5: 7,5$ & $\begin{array}{l}\text { not deformed, } \\
\text { do not stick together }\end{array}$ & 2,05 & 6,52 & 7 & the transparent \\
\hline $90: 10$ & $\begin{array}{l}\text { not deformed, } \\
\text { do not stick together }\end{array}$ & 1,99 & 6,71 & 7 & the transparent \\
\hline $87,5: 12,5$ & $\begin{array}{l}\text { not deformed, } \\
\text { do not stick together }\end{array}$ & 1,91 & 6,94 & 7 & the transparent \\
\hline $85: 15$ & $\begin{array}{l}\text { not deformed, } \\
\text { do not stick together }\end{array}$ & 1,86 & 7,03 & 7 & the transparent \\
\hline $82,5: 17,5$ & $\begin{array}{l}\text { not deformed, } \\
\text { do not stick together }\end{array}$ & 1,84 & 7,12 & 7 & the transparent \\
\hline $80: 20$ & $\begin{array}{l}\text { not deformed, } \\
\text { do not stick together }\end{array}$ & 1,79 & 7,38 & 7 & the transparent \\
\hline $77,5: 22,5$ & little stick & 1,68 & 8,48 & 8 & not transparent \\
\hline $75: 25$ & little stick & 1,57 & 8,58 & 8 & not transparent \\
\hline $95: 5$ & $\begin{array}{l}\text { not deformed, } \\
\text { do not stick together }\end{array}$ & 2,15 & 6,2 & 6 & the transparent \\
\hline $92,5: 7,5$ & $\begin{array}{l}\text { not deformed, } \\
\text { do not stick together }\end{array}$ & 2,08 & 6,38 & 6 & the transparent \\
\hline $90: 10$ & $\begin{array}{l}\text { not deformed, } \\
\text { do not stick together }\end{array}$ & 2,04 & 6,62 & 7 & the transparent \\
\hline $87,5: 12,5$ & $\begin{array}{l}\text { not deformed, } \\
\text { do not stick together }\end{array}$ & 1,98 & 6,83 & 7 & the transparent \\
\hline $85: 15$ & $\begin{array}{l}\text { not deformed, } \\
\text { do not stick together }\end{array}$ & 1,9 & 7,02 & 7 & the transparent \\
\hline $82,5: 17,5$ & $\begin{array}{l}\text { not deformed, } \\
\text { do not stick together }\end{array}$ & 1,86 & 7,10 & 7 & the transparent \\
\hline $80: 20$ & $\begin{array}{l}\text { not deformed, } \\
\text { do not stick together }\end{array}$ & 1,81 & 7,25 & 7 & the transparent \\
\hline $77,5: 22,5$ & little stick & 1,69 & 8,28 & 7 & the transparent \\
\hline $75: 25$ & little stick & 1,63 & 8,42 & 8 & the transparent \\
\hline
\end{tabular}




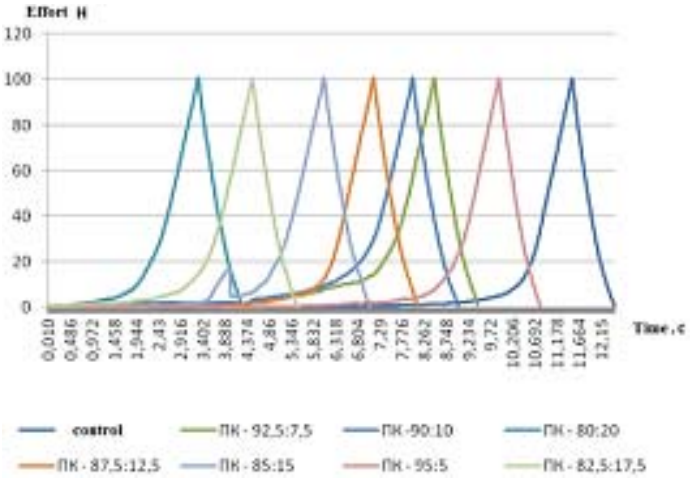

a) the wheat and corn;

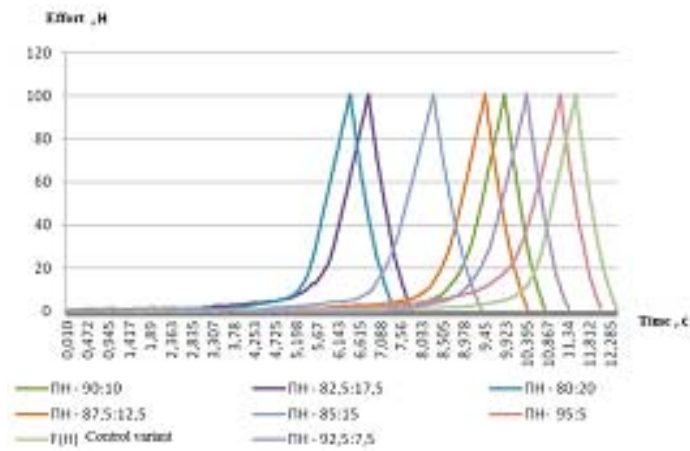

b) wheat chickpea

Fig. 1. The changing of elastic and plastic deformations of dough without ion ozonated water

$10,0-12,5 \%$ led introduction of flour from grain and bean crops to receiving pasta of unsatisfactory quality. On a condition of a surface dry pasta was smooth with small rough nesses or rough, color of products worsened to a light gray, gray and yellow shade. Acidity of pasta I increased. The welded products were characterized by very viscous consistence, got out of a shape and stuck together among themselves.

Thus, the conducted researches showed that cornmeal additives in number of $10 \%$, chickpea flour - $12,5 \%$ had the most positive impact on quality of ready pasta.

\section{DISCUSSION}

For decrease in the worsening influence of corn and chickpea flour on technological properties of pasta in work ion ozonated water with concentration of ozone of $2 \mathrm{mg} / \mathrm{l}$ and concentration of ions $500,1000,1500$ pieces/cm3 was used. Concentration of ozone in ion ozonated water was taken by $2 \mathrm{mg} / \mathrm{l}$, proceeding from works [6] of the ozonized water devoted to application in production of bread and pasta.

For the purpose of definition of possible dosages of flour in a compounding at use of ion ozonated water made pasta with introduction of grain and bean crops corn and chickpea at a dough batch in quantity from 5 up to $25 \%$ of the mass of wheat flour. (Henney,2010;)

The using of ion ozonated water at a batch of pasta dough on the basis of corn and chickpea flour has improved rheological properties of dough, organoleptic, physical and chemical, cooking properties of pasta, thus the best results are being reached at use of ion ozonated water with concentration of ions of 1000 pieces $/ \mathrm{cm} 3$.

The results of research of influence of ion ozonated water of optimum concentration (concentration of ozone of $2 \mathrm{mg} / \mathrm{l}$ and ions of 1000 pieces $/ \mathrm{cm} 3$ ) on cooking properties of pasta are given in table 3 .

According to data of the table the 3rd coefficient of increase in mass of products improves in comparison with samples without ion ozonated water. So, in process of increase in the content of cornmeal from 5 to $25 \%$ the coefficient $(\mathrm{Km})$ increases by $10,5-12,1 \%$, chickpea - for $11,9-$ $10,2 \%$ in comparison with samples without ion ozonated water. Duration of cooking increases respectively on $0-27,3 ; 14,3-20,0 \%$.Use of ion ozonated water allowed to reduce transition of solids to cooking water. In process of increase in cornmeal from 5 to $25 \%$ the amount of the solids which passed into cooking water decreases by 6,6 $13,3 \%$ at concentration of ions of 500 pieces $/ \mathrm{cm} 3$, for $9,0-16,7 \%$ - at concentration of ions of 1000 pieces/cm 3 , for $1,3-3,2 \%$ - at concentration of ions of 1500 pieces $/ \mathrm{cm} 3$. At use of chickpea flour decreases respectively on 5,7-11,9; 8,8-15,5 and 0 $1,2 \%$ in comparison with samples without ion ozonated water. (Henney,2010;)

Thus, the received results of researches show that use of ion ozonated water at a batch of pasta dough with use of flour of grain and bean crops improved organoleptic, physical and chemical, cooking indicators of pasta in comparison 
with samples without use of ion ozonated water. The best quality of pasta is reached at use of ion ozonated water with concentration of ozone of 2 $\mathrm{mg} / \mathrm{l}$ and ions of $1000 \mathrm{pieces} / \mathrm{cm} 3$ and at a ratio: wheat cornmeal 80:20, wheat chickpea -80:20.

\section{CONCLUSION}

On the basis of results of researches of influence of corn and ñhickpea flour on rheological properties of dough and quality of ready pasta optimum dosages of cornmeal of $10 \%$ are established, chickpea flour of $12,5 \%$ to the mass of wheat flour of the first grade, the further increase in dosages of corn and chickpea flour leads to deterioration of technological properties of pasta.

It is established that use of ion ozonated water at preparation of dough promotes improvement of rheological properties of dough and quality of pasta; it is defined that from the point of view of improvement of quality of pasta by an optimum dosage of corn and ñhickpea flour $20 \%$, concentration of ozone of $2 \mathrm{mg} / \mathrm{l}$ and ions of 1000 pieces $/ \mathrm{cm} 3$ in ion ozonated water are being. Use of flour from grain and bean crops expediently for enrichment of pasta valuable food components - proteins, irreplaceable amino acids, vitamins and mineral substances. (Iskakova et al, 2011;)

\section{REFERENCES}

1. Medvedev of G. M. Technology of pasta. - SPb.: GIORD, 2005; 312s. doi: 10.1080/ 10408390903001693.

2. Osipova G. A., Koryachkina S. Ya. Development of a way of increase of biological value of pasta from baking flour//Bread baking of Russia.-2002; 6: 15-17. doi:10.1017/S0022029912000313

3. Kosovan A.P., Polandova R. D. New conceptual solutions of problems of the baking and pasta industry//Storage and processing of agricultural raw materials2004; 6: 49-51. DOI:10.1080/ 10408390903001693

4. Kizatova M. Zh., Iztayev A.I. Scientific bases of processing of grain of corn for its reproduction and industrial processing. - Almaty, Aleurone.2006; 198. DOI:10.1007/s11947-015-1476-1

5. Pashchenko L.P., Kurchayeva E.E. Some data on chick-pea and its application in food//Storage and processing of agricultural raw materials.2004; 4: 59-60. DOI:10.1002/jsfa.7176

6. Iskakova G. K., Iztayev A.I., Kulazhanov T.K.,
Mayemerov M. M., Iztayev of B. A. Technology of bread and pasta with use of the ozonized and ion ozonated water (monograph). - Almaty: ATU, 216pages. DOI: 10.1111/j.17454603.2011.00305.x

7. Erkebayev M. Zh., Kulazhanov T.K., Medvedkov E.B. Bases of a Technology of foodstuff. - Almaty, 2006; 298 pages. DOI:10.1007/s12393-015-9117-z

8. A laboratory workshop on the general technology of food productions / Under the editorship of L.P. Kovalskaya. - M.: Agropromizdat, 1991; 336s. DOI:10.1111/jfpp.12172

9. Harper, J.M. . "Food extrusion". Critical Reviews in Food Science and Nutrition, 1978. DOI:10.1016/j.tifs.2013.10.007

10. Akdogan H. "High moisture food extrusion". International Journal of food Science \& Technology . (June 1999) doi:10.1111/j.17454603.2011.00305.x

11. Jane E Henney, Christine L Taylor, and Caitlin S Boon, ed.. Strategies to Reduce Sodium (2010) DOI: $10.4236 /$ fns. 2012.34062

12. Karwe V. "Food extrusion". Food Engineering 3. Oxford Eolss Publishers Co Ltd 2008. DOI: $10.1039 / C 4 R A 11857 J$

13. Camire, M.E. "Chemical changes during extrusion cooking. Recent advances.". Advances in Experimental Medicine and Biology 1998. doi.org/10.1094/CC-82-0321

14. Beaufrand M.J.). "Effect of the extrusion process on the availability of proteins". Annales de la nutrition et de l'alimentation 1978. DOI: 10.3923/jftech.2010.159.168 Guy, Robin, Extrusion Cooking: Technologies and Applications. Cambridge: Woodhead Publishing. (2001). pp. 111-116.

15. Brennan, Margaret A.; Monro, John A.; Brennan, Charles S.."Effect of inclusion of soluble and insoluble fibres into extruded breakfast cereal products made with reverse screw configuration". International Journal of Food Science \& Technology, 2008; DOI: 10.2298/ APT1445023F

16. Napolina L. Napolina's pasta range also includes a premium bronze die pasta which is extruded through bronze dies to create a rough, porous surface. 2008 DOI: 10.1021/jf0606095

17. Shivendra Singh, Shirani Gamlath, Lara Wakeling "Nutritional aspects of food extrusion: a review”. International Journal of Food Science \& Technology, 2007. DOI: 10.3923/ jftech.2010.159.168

18. Brennan, Margaret A.; Menard, Carine; Roudaut, Gaëlle; Brennan, Charles S.. ”Amaranth, millet and buckwheat flours affect the physical 
properties of extruded breakfast cereals and modulates their potential glycaemic impact” 2012 DOI: 10.1002/jsfa.2673

19. Heldman, Dennis R.; Hartel, Richard W. Principles of Food Processing. 1997. DOI:10.1021/acs.nanolett.5B01202
20. Zuber, F.; Mégard, D.; Cheftel, J.C. “Continuous emulsification and gelation of dairy ingredients by HTST extrusion cooking: production of processed cheeses". International Journal of Food Science \& Technology. 1987. DOI:10.1021/ acs.nanolett.5B01531 